\title{
Mechanical Properties of Epoxy Resins Filled with Waste Rubber Powder
}

Petr Valášek

Faculty of Engineering, Czech University of Life Sciences Prague. Kamýcká 129, 165 21, Prague. Czech Republic. Email: valasekp@tf.czu.cz

\begin{abstract}
A material usage of waste rubber powder in the polymeric composites increases their significance. Material recycling is very important ways of dealing with waste. The paper deals with laboratory tests of polymeric particle composites based on the waste - rubber powder which was gained as one of outputs of a recycling line. The paper describes mechanical properties of these composite systems such as: hardness (Shore D, Brinell), tensile strength (cohesive strength of filled epoxy resins) and it is also focused on the lap-shear tensile strength in the boundary adherend. Adding waste rubber powder into the epoxy resins and into other plastics materials and adhesives is a way for the material recycling which is inexpensive and sensitive to the environment. The inclusion of filler lead to the fall of lap-shear tensile strength values with an increasing amount of filler and to stabilizing on the level 520 vol.\% filler in the epoxy matrix.
\end{abstract}

Keywords: Hardness, Lap-shear tensile strength, Recycling

\section{Acknowledgement}

This paper has been done when solving the grant IGA TF.

\section{References}

[1] FANG, Y., ZHAN, M., WANG Y. (2000). The status of recycling of waste rubber. In: Materials and Design, Vol. 22, No. 2, pp. $123-127$.

[2] MLEZIVA, J. (1993). Polymery: výroba, struktura, vlastnosti a použití. (Polymers: manufacture, structure, properties and applications), Prague -Sobotáles.

[3] XIA, J., XIAOMEI, L. (2005). Influence of $\mathrm{Al}_{2} \mathrm{O}_{3}$ reinforcement on the abrasive wear characteristic of $\mathrm{Al}_{2} \mathrm{O}_{3} / \mathrm{PA} 1010$ composite coatings. In: Wear, Vol. 258, pp. $1342-1347$.

[4] SATAPATHY, B.K., BIJWE, J. (2002). Analysis of simultaneous influence of operating variables on abrasive wear of phenolic composites. In: Wear, Vol. 253, pp. $787-794$.

[5] MOHAN, N., NATARAJAN, S., KUMARESH BABU, S.P. (2012). The role of synthetic and natural fillers on three-body abrasive wear behaviour of glass fabric-epoxy hybrid composites. In: Journal of applied polymer science, Vol. 124, pp. $484-494$.

[6] VALÁŠEK, P., MÜLLER, M. (2012). Polymeric particle composites with filler saturated matrix. Manufacturing Technology, Vol. 12, Nr. 13, pp. $272-276$.

[7] KEJVAL, J., MÜLLER, M., HENC, P. (2012). Mechanické vlastnosti a „two-body“ abrazivní opotřebení polymerních částicových kompozitů. Strojírenská technologie, Nr. 1,2, pp. $33-38$.

[8] MÜLLER, M., VALÁŠEK, P. (2012). Abrasive wear effect on Polyethylene, Polyamide 6 and polymeric particle composites. Manufacturing Technology, Vol. 12, pp. 55 - 59.

[9] VALÁŠEK, P., MÜLLER, M. (2013). Changes of Polyurethane Mechanicla Properties Filled with Glass Powder. In: Manufacturing Technology, Vol.13, No.4, pp.563 - 568.

[10] VALÁŠEK, P., MÜLLER, M. (2013). Composite based on hard-cast irons utilized on functional parts of tools in agrocomplex. In: Scientia Agriculturae Bohemica, Vol. 44, No. 3, pp. 172 - 177.

[11] MÜLLER, M. (2013). Research of Renovation Possibility of Machine Tools Damage by Adhesive Bonding Technology. In: Manufacturing Technology, Vol.13, No.4, pp.504-509.

[12] KU, H., TRADA, M. et al. (2010). Tensile Tests of Phenol Formaldehyde Glass-Powder Reinforced Composites: Pilot Study. In: Journal of applied polymer science, Vol. 116, pp. $10-17$.

[13] CERBU, C., CURTU, I. (2011). Mechanical characterization of the glass fibres/rubber/resin composite material. In: Materiale Plastice, Vol. 48, No. 1, pp. 93 - 97. 
[14] SUBRAMANIYAN, S.K., MAHZAN, S. et al. (2012). Mechanical behavior of polyurethane composite foams from kenaf fiber and recycled tirerubber particles. In: Applied Mechanics and Materials 3rd International Conference on Mechanical and Manufacturing Engineering, ICME 2012; November, pp. 861 - 866.

[15] CSN EN ISO 3167. (2004). Plastics - Multipurpose test specimens. Czech Standards Institute.

[16] NOVÁK, M. (2011). Surface duality hardened steels after grinding. In: Manufacturing technology, Vol. 11, pp. $55-59$.

[17] RUGGIERO, A., SENATORE, A. (2007). Approximate closed - form solution for the dynamical analysis of short bearings with couple stress fluid. Lubrication Science, Vol. 19, No. 4, pp. 247-267.

[18] CSN EN 1465. (1997). Adhesives - Determination of tensile lap-shear strength of rigid-to-rigid bonded assemblies. Czech Standards Institute.

[19] VALÁŠEK, P., ŽARNOVSKÝ, J., MÜLLER, M. (2013). Thermoset composite on basis of recycled rubber. In: Advanced materials research, Vol. 801, pp. $67-73$.

Copyright (C) 2014. Published by Manufacturing Technology. All rights reserved. 